\title{
The Influence of Business With Content Ecommerce on Retail Business To The Aspect Marketing of Micro Small Medium In Depok
}

\author{
Sugeng Haryono ${ }^{1}$, Nurlaela ${ }^{2}$ \\ Fakultas Teknik dan Ilmu Komputer, Universitas Indraprasta PGRI, Jakarta, Indonesia ${ }^{1}$ \\ Fakultas Teknik dan Ilmu Komputer, Universitas Indraprasta PGRI, Jakarta, Indonesia ${ }^{2}$
}

\begin{abstract}
There are many factor that affect the rapid development of online busniness in Indonesia among the more eccommerce users. Associated with this researcher will examine about the influence of business with content ecommerce on retail business to the aspect marketing of micro small medium in Depok. Specific objectives of this research are 1). To help retail business managers maximize distribution, information and product socialization to be easily accessible by the community so as to be able to compete with business managers with ecommerce content. 2). the process of socialization, product education, marketing and product data processing through ecommerce. As for the results of the research, there is a significant effect of e-commerce content on retail business on the marketing aspect of Micro Small Medium in Depok
\end{abstract}

Keyword. ecommerce; retail business; micro small medium

Article history. Received January, 2018. Revised March, 2018. Accepted June, 2018

Corresponding author. sugeng.unindra@gmail.com

How to cite article. Haryono, S., \& Nurlaela, N. (2018). the Influence of Business With Content Ecommerce on Retail Business To the Aspect Marketing of Micro Small Medium in Depok. The International Journal of Business Review (The Jobs Review), 1(1), 1-8. https://doi.org/10.17509/tjr.v1i1.11724

\section{INTRODUCTION}

Business online now middle so the Belle among lovers shopping Homeland. It is seen from the rise of online store the emerging from small, individuals to the company large corporate professional. This fact the cornering retail business or conventional has long been a daily life of the people of Indonesia. There are many factors that affect the rapid development of an online business in Indonesia among users ecommerce that more and more according to data from the government, the number of Internet users in Indonesia has more than half of the total population of which $57 \%$ or more precisely around 137 million, the figure is expected to continue to grow from time to time. Social media is one of the media easiest to promote a goods, given the number of users sosmed in Indonesia at this time. Online business not only by 'new players' pure use the Internet as media business. Despite the fact online business more promising and growth the leaps and bounds, this is not going to turn off the full retail business. This is because not all business entirely can be done online, for example of raw materials and groceries. You certainly not need online if you just want to buy chili not? See the facts on top, which should be done by the business people retail is start using online media / ecommerce as a means of their business, especially for the promotion.

Electronic commerce is defined as the process of purchasing and selling of products, services and information that is done electronically by utilizing the internet. E-commerce from several perspectives, including from the perspective of communication, e-commerce is the delivery of information, products, services, or payments through telephone network or communications path. From the perspective of business processes, e-commerce is the 
application of technology to automate business transactions and work flow. From a service perspective, e-commerce is a tool used to reduce costs in ordering and shipping.

Retailer or retail sale or otherwise known as retail is a trading business activity (the sale of goods or services) which is directly channeled to the end consumer for use as personal, family or household needs not for resale. According to Hendri Ma'ruf (2005: 71), retail is a business activity selling goods or services to individuals for the purposes of self, family or household. While retailers are entrepreneurs who sell goods or services in retail to the public as consumers, retail perorang or small retailers have a number of outlets vary, ranging from one to more outlets. According to Tjiptono (2008: 191), Retailers (retailling) represent all activities of selling goods and services directly to end consumers for personal and household use, not for business purposes. According to Kotler (2007: 592), retailing is all activities involving the sale of goods and services directly to the end consumer for personal use rather than for business.

Retail or also called retail is one way of product marketing includes all activities that involve the sale of goods directly to the end consumer for personal and non-business use. The organization or someone who runs the business is also called a reseller. In practice, retailers purchase large quantities of goods or products from producers, or importers either directly or through wholesalers, and then resell them in small quantities.

Marketing is an activity, a set of institutions, and the process of creating, communicating, delivering and exchanging valuable offers for customers, clients, partners and the general public

Philip Kotler Marketing is a human activity directed to meet the needs and desires through the exchange process. According to Philip Kotler and Armstrong marketing is as a social and managerial process that allows individuals and groups to get what they need and want through the creation and exchange of mutual products and value with others.

\section{METHOD}

The sampling technique in the research is based on random stratification technique from the Micro Small Medium entrepreneur in Depok Region. The determination of this sample refers to the opinion (Arikunto 1998: 107) that if the research object is greater than 100 respondents taken $10 \%$ to $15 \%$, or $20 \%$ up $30 \%$ but if less than 100 respondents, the respondent or sample is taken entirely. The number of population in this research is 50 businessman Creative Bond Assosiciation Depok area (Asosiasi Ikatan Kreatif Depok). Based on this, the sample is obtained by taking $100 \%$ of the population. Thus, the number of samples is 50 entrepreneurs in Depok. The sample calculations are as follows. Food entrepreneurs 20, entrepreneurs textil 20, Entrepreneurs Handmade 10.

\section{RESULTS AND DISCUSSION}

In the description of the data as a whole in two variables are as follows.

Table 1. Statistics

\begin{tabular}{llcc}
\hline & & $\begin{array}{c}\text { Content } \\
\text { Ecommerce }\end{array}$ & $\begin{array}{c}\text { Aspect Of Marketing Micro } \\
\text { Small Medium }\end{array}$ \\
\hline $\mathrm{N}$ & Valid & 50 & 50 \\
Mean & Missing & 0 & 0 \\
Median & & 37.58 & 30.62 \\
\hline
\end{tabular}

2 | The International Journal of Business Review (The Jobs Review) Vol.1 | No.1 |2018 


\begin{tabular}{lcc}
\hline & $\begin{array}{c}\text { Content } \\
\text { Ecommerce }\end{array}$ & $\begin{array}{c}\text { Aspect Of Marketing Micro } \\
\text { Small Medium }\end{array}$ \\
\hline Mode & 34 & $27^{\mathrm{a}}$ \\
Std. Deviation & 4.257 & 3.206 \\
Variance & 18.126 & 10.281 \\
Skewness & .694 & .329 \\
Std. Error of & .337 & .337 \\
Skewness & .385 & -1.044 \\
Kurtosis & .662 & .662 \\
Std. Error of & 20 & 11 \\
Kurtosis & 30 & 26 \\
Range & 50 & 37 \\
Minimum & 1879 & 1531 \\
Maximum & Sum &
\end{tabular}

a. Multiple modes exist. The smallest value is shown

E-commerce content influence data obtained maximum score 50, minimum 30, mean 37,58 , media 37,00 , mode equal to 34 , standard deviation equal to 4,257. From the description can also be seen that the average value and median almost the same, that is 37.58 and 37.00. This shows that the e-commerce content score data in this study is quite representative. Description of data can be seen from Histogram in figure 5.1 ..

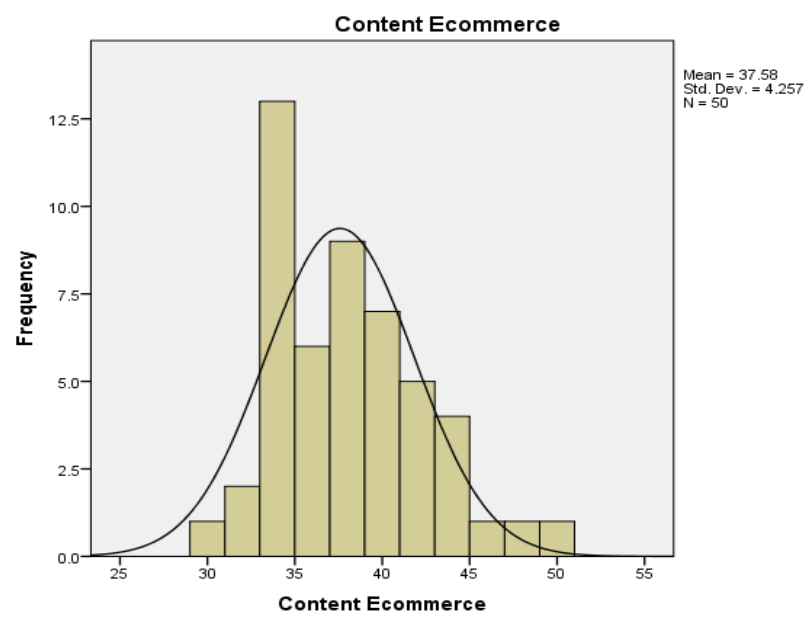

Figure 1. E-Commerce Content Histogram.

From the histogram and polygon frequency above can be concluded that the data rate of the use of e-commerce content in this study has a distribution that tends to normal. Because the shape of the curve approaches the normal form.

Table 2. Data Normality Test

One-Sample Kolmogorov-Smirnov Test

\begin{tabular}{|c|c|c|c|}
\hline & & $\begin{array}{c}\text { Content } \\
\text { Ecommerce }\end{array}$ & $\begin{array}{l}\text { Aspect Of Marketing } \\
\text { Micro Small Medium }\end{array}$ \\
\hline $\mathrm{N}$ & & 50 & 50 \\
\hline Normal Parameters ${ }^{\mathrm{a}, \mathrm{b}}$ & Mean & 37.58 & 30.62 \\
\hline
\end{tabular}

3 | The International Journal of Business Review (The Jobs Review) Vol.1 | No.1 | 2018 


\begin{tabular}{llcc}
\hline & & $\begin{array}{c}\text { Content } \\
\text { Ecommerce }\end{array}$ & $\begin{array}{c}\text { Aspect Of Marketing } \\
\text { Micro Small Medium }\end{array}$ \\
\hline & Std. & 4.257 & 3.206 \\
Deviation & .120 & .133 \\
Most Extreme & Absolute & .120 & .133 \\
Differences & Positive & -.081 & -.091 \\
Kolmogorov-Smirnov Z Z & Negative & .847 & .943 \\
Asymp. Sig. (2-tailed) & .470 & .337 \\
\hline
\end{tabular}

a. Test distribution is Normal.

b. Calculated from data.

From the table above shows that the hypothesis test that states the distribution of data in this regression analysis follows the normal distribution. This is indicated by all Kolmogorov-Smirnov $\mathrm{Z}$ values $>0.05$. This means that all data is normally distributed.

Table 3. Multicollinearity Test

Coefficients

\begin{tabular}{llll}
\hline Model & & \multicolumn{2}{c}{$\begin{array}{c}\text { Collinearity } \\
\text { Statistics }\end{array}$} \\
\cline { 3 - 4 } & & $\begin{array}{l}\text { Tolera } \\
\text { nce }\end{array}$ & VIF \\
\hline 1 & $\begin{array}{l}\text { (Constant) } \\
\text { Content } \\
\text { Ecommerce }\end{array}$ & 1.000 & 1.000 \\
\hline
\end{tabular}

a. Dependent Variable: Aspect Of

Marketing Micro Small Medium

In the above table it is known that the results of Tolerance and the variant inflation factor (VIF) in each independent variable used has a tolerance value greater than $0.1(10 \%)$ and VIF is smaller than 10 . So it can be stated that there is no multicolinearity in this research.

Table 4. Error Normality Test

ANOVA Table

\begin{tabular}{|c|c|c|c|c|c|c|c|}
\hline & & & $\begin{array}{l}\text { Sum of } \\
\text { Squares }\end{array}$ & Df & $\begin{array}{l}\text { Mean } \\
\text { Square }\end{array}$ & $\mathrm{F}$ & Sig. \\
\hline \multirow{8}{*}{$\begin{array}{l}\text { Aspect } \\
\text { Of } \\
\text { Marketin } \\
\text { g Micro } \\
\text { Small } \\
\text { Medium } \\
\text { * Content } \\
\text { Ecommer } \\
\text { ce }\end{array}$} & & $\begin{array}{l}\text { (Comb } \\
\text { ined) }\end{array}$ & 311.905 & 16 & 19.494 & 3.353 & .002 \\
\hline & Betw & $\begin{array}{l}\text { Linear } \\
\text { ity }\end{array}$ & 243.468 & 1 & 243.468 & 41.873 & .000 \\
\hline & $\begin{array}{l}\text { een } \\
\text { Grou }\end{array}$ & Deviat & & & & & \\
\hline & ps & $\begin{array}{l}\text { 10n } \\
\text { from }\end{array}$ & 68.437 & 15 & 4.562 & .785 & .685 \\
\hline & & $\begin{array}{l}\text { Linear } \\
\text { ity }\end{array}$ & & & & & \\
\hline & \multirow{3}{*}{\multicolumn{2}{|c|}{$\begin{array}{l}\text { Within } \\
\text { Groups } \\
\text { Total }\end{array}$}} & 101875 & 33 & 5814 & & \\
\hline & & & 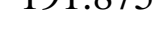 & נJ & 0.014 & & \\
\hline & & & 503.780 & 49 & & & \\
\hline
\end{tabular}

4 | The International Journal of Business Review (The Jobs Review) Vol.1 | No.1 | 2018 
Based on the above results perhiungan obtained Deviation from Linearity calculation results with Fo $=0.785$ and Sig. $=0.685>0.05$. This has the sense that the MSME marketing aspects of ecommerce content have a linear relationship

Table 5. Test Results Linearity Regression Variable Y over X One-Sample Kolmogorov-Smirnov Test

\begin{tabular}{llr}
\hline & & $\begin{array}{c}\text { Unstandardized } \\
\text { Residual }\end{array}$ \\
\hline $\mathrm{N}$ & Mean & 50 \\
Normal Parameters & a,b & Std. \\
& Deviation & 2.30488294 \\
Most Extreme & Absolute & .105 \\
Differences & Positive & .060 \\
Kolmogorov-Smirnov Z & Negative & -.105 \\
Asymp. Sig. (2-tailed) & & .745 \\
\hline
\end{tabular}

a. Test distribution is Normal.

b. Calculated from data.

From the table above shows that the hypothesis test which states the residual distribution in this regression analysis follows the normal distribution. This is indicated by the value of $Z=0.745$ and Sig. $=0.635>0.05$. This means the assumption or requirement of regression analysis is met.

Table 6. The Result of Correlation Coefficient of Influence of Variable X on Variable Model Summary

\begin{tabular}{lcccr}
\hline Model & R & R Square & $\begin{array}{c}\text { Adjusted R } \\
\text { Square }\end{array}$ & $\begin{array}{l}\text { Std. Error of } \\
\text { the Estimate }\end{array}$ \\
\hline 1 & $.695^{\text {a }}$ & .483 & .473 & 2.329 \\
\hline a. Predictors: (Constant), Content Ecommerce
\end{tabular}

Table 7. Recapitulation of Calculation Result Calculation Testing Signification Regression Coefficient Influence Variable X1 to Variable Y

\begin{tabular}{rlrrrrr}
\multicolumn{7}{c}{ ANOVA $^{\text {a }}$} \\
\hline Model & & Sum of & df & Mean & F & Sig. \\
& & Squares & & Square & & \\
\hline \multirow{3}{*}{1} & Regression & 243.468 & 1 & 243.468 & 44.894 & $.000^{\text {b }}$ \\
& Residual & 260.312 & 48 & 5.423 & & \\
& Total & 503.780 & 49 & & & \\
\hline
\end{tabular}

a. Dependent Variable: Aspect Of Marketing Micro Small Medium

b. Predictors: (Constant), Content Ecommerce 
Table 8. Recapitulation of Calculation Result of Line Regression Equation of Influence of Variable $\mathrm{X} 1$ on Variable Y

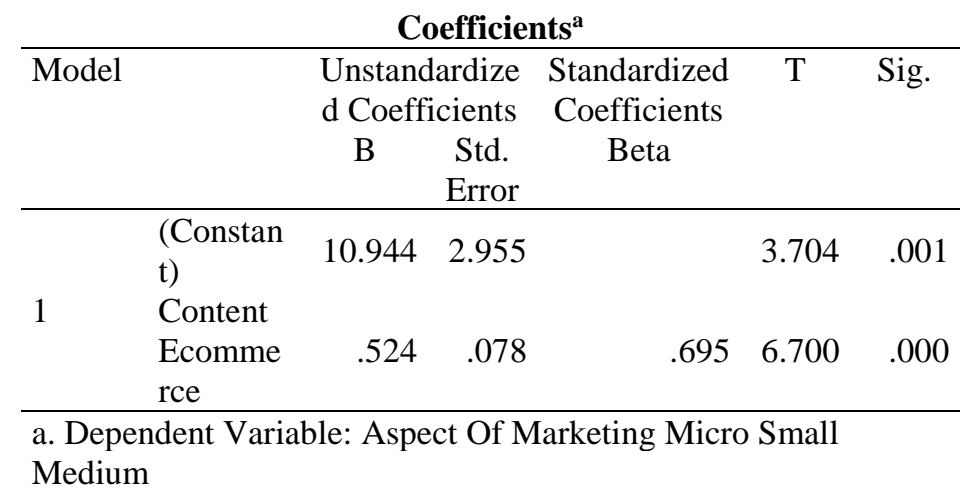

Perlain Content Influence on Retail Business (X) on Marketing Aspect of Micro Small Medium Enterprises (Y)

Hypothesis tested:

HO: $(=0$

H1: $(\neq 0$

Means:

$\mathrm{H} 0$ : There is no effect of e-commerce content on retail business to the marketing aspect of Micro Small Medium Enterprises

H1: There is the effect of e-commerce content on retail business to the marketing aspect of Micro Small Medium Enterprises.

From table 4.6 above, it can be seen that the correlation coefficient of the influence of e-commerce content free variable on retail business $(\mathrm{X})$ on marketing aspect of Micro Small Medium Enterprises (Y) is 0.695.

Calculation testing significance of this correlation coefficient can be seen in Appendix Hypothesis. From the calculation is obtained that the correlation coefficient is significant, in other words that there is significant influence of E-commerce content variable on retail business (X) on marketing aspect of Micro Small Medium Enterprises (Y).

While the determination coefficient of 0.483 indicates that the contribution of e-commerce content on retail business $(\mathrm{X})$ to the marketing aspect of Micro Small Medium Enterprises (Y) is $48.3 \%$, the rest $(51.7 \%)$ due to the influence of other factors.

As for hypothesis testing through regression analysis obtained calculation results seen in Table 5.7.dan Table 5.8. From Table. 5.8. obtained by regression line equation which represent influence of variable $\mathrm{X}$ increment variable $\mathrm{Y}$, that is $=10,944+0,524 \mathrm{X}$.

While testing the significance of the regression line is to pay attention to the results of the existing calculations in Table 5.7. According to the existing provisions, the criterion of regression significance is "if Sig <0.05 then $\mathrm{HO}$ is rejected" or "if Fcount> Ftable then $\mathrm{H} 0$ is rejected", which means that the regression coefficient is significant, in other words there is a significant influence of independent variable $X$ to variable bound $Y$. The Sig value is the number shown in the Sig column in Table 5.7. The value of Fhitung is the number shown in column F in Table 5.7. While the Ftable value is the value of the F distribution table for the

6 | The International Journal of Business Review (The Jobs Review) Vol.1 | No.1 | 2018 
real level of $5 \%$ with the degree of the numerator $(\mathrm{k})=2$ and the degree of denominator $(\mathrm{n}$ $\mathrm{k}-1)=48$ where $\mathrm{n}$ is the number of respondents, and $\mathrm{k}$ is the number of independent variables.

From Table 5.7 it can be seen that the value of $\operatorname{Sig}=0.000<0,05$ and Fhitung $=44,894$ then $\mathrm{H} 0$ is rejected which means that the regression coefficient is significant. In other words, there is a significant effect of e-commerce content on retail business $(\mathrm{X})$ on marketing aspect of Micro Small Medium Enterprise (Y).

From the above output can be know tct value $=6,700$ with significance value 0,000 $<0.05$ then $\mathrm{H} 0$ is rejected and $\mathrm{H} 1$ accepted which means there is a significant effect of ecommerce content on retail business (X) on marketing aspect of Micro Small Medium Enterprises (Y ). From the results of regression testing it can be concluded that there is the influence of e-commerce content on the retail business $(\mathrm{X})$ on the marketing aspect of Micro Small Medium Enterprises (Y).

\section{CONCLUSION}

Based on the description of research data and after the analysis it can be concluded: There is a significant effect of e-commerce content on retail business on the marketing aspect of Micro Small Medium Enterprises in Depok. And there is a significant effect of ecommerce content on retail business on the marketing aspect of Micro Small Medium Enterprises in Depok. Suggestions that writers can convey on this occasion are as follows (1) For entrepreneurs of Micro Small Medium Enterprises in Depok city is expected to implement Information Technology in the form of e-commerce, can become a consideration for business actor. Because in e-commerce in addition to buying and selling transactions, companies can also exchange information through the Internet network. (2) For Depok city government is expected to provide coaching and training so that the entrepreneurs of Micro Small Medium Enterprises are more motivated in marketing the existing products. (3) For the next researcher, you can develop research on what ideas that drive companies to use ecommerce in the interests of business and how much benefit has been made if companies have implemented e-commerce in their business interests.

\section{REFERENCES}

Bilson Simamora. (2003). Paduan Riset perilaku Konsumen. Jakarta : PT. Gramedia Pustaka Utama.

Hendri.M. (2005). Pemasaran Ritel. Jakarta : PT. Gramedia Pustaka Utama.

Kotler. P. (2007). Manajemen Pemasaran. Yogyakarta : PT.Prenhalindo.

Philip, Kotler. 2000. Manajemen Pemasaran Edisi Milenium Jilid $1 \& 2$. Prenhalindo: Jakarta.

Tjiptono. F.(2008). Strategi Pemasaran. Edisi 3. Yogyakarta : ANDI.

Drs Syahri Alhusin,MS. 2002. Aplikasi Statistik Praktis dengan SPSS.10. Graha Ilmu. Surakarta

Shortcourse Series. 2010. Mudah Belajar Statistik SPSS 18. Wahana Komputer. Semarang. 